\title{
Molecular Characterization of a Rigid Rod-Shaped Virus Isolated from Frangipani (Plumeria sp.) Showing Mosaic Symptom in Taiwan
}

\author{
Fery Abdul Choliq ${ }^{1^{*}}$, Tsang-Hai Chen ${ }^{2}$, Liliek Sulistyowati ${ }^{3}$ \\ ${ }^{1,3}$ Department of Plant Protection, Faculty of Agriculture, University of Brawijaya, Malang, Indonesia \\ ${ }^{2}$ Department of Plant Medicine, National Pingtung University of Science and Technology, Pingtung, Taiwan
}

\begin{abstract}
Frangipani is an important succulent plant around the worlds and also in Taiwan, for example, Plumeria rubra is widely grown as a popular ornamental tree in parks and landscaped establishments in Taiwan. Recently, a new disease in frangipani with mosaic and distortion symptoms was found in Taiwan. No viruses caused frangipani disease has been reported in Taiwan and the references about frangipani disease are still limited and only Frangipani mosaic virus (FrMV) was found. In this study, the molecular properties of a virus isolated from symptomatic frangipani in south Taiwan, such as Pingtung, Kauhsiung and Tainan were investigated. The virus with rod-shaped particles of $300 \mathrm{~nm}$ long and $18 \mathrm{~nm}$ in diameter was examined inside diseased leaves by electron microscopy. The purified virus particles showed the typical UV spectrum of tobamoviruses with $A_{260} / A_{280}$ value of 1.29 and maximum and minimum absorption at $260 \mathrm{~nm}$ and 249 $\mathrm{nm}$, respectively. The molecular weight of $19.5 \mathrm{kDa}$ as the size of coat protein of tobamoviruses was estimated by sodium dedocyl sulfate-polyacrylamide gel (SDS-PAGE). Furthermore, the degenerate primers for tobamoviruses were used to amplify $568 \mathrm{bp}$ and $400 \mathrm{bp}$ of the DNA fragments in RT-PCR and nested PCR, respectively. Based on these results, it was confirmed that the rigid rod-shaped virus isolated from mosaic symptom of frangipani leaves is an isolate of FrMV, belonging to the genus Tobamovirus. This is the first report thatFrMV infecting Plumeria sp. in Taiwan.
\end{abstract}

Keywords: Frangipani plant, FrMV, mosaic disease, Tobamovirus.

\section{INTRODUCTION}

Frangipani (Plumeria sp.) is a small group of plant species native to tropical countries [1]. Frangipani is an important succulent plant around the worlds and some species are valuable sources as medicines, insecticides, fibers, and rubber [2]. Frangipani plants are also important in Taiwan.

For the example is $P$. rubra which widely grown as a popular ornamental tree in parks and landscaped establishments in Taiwan. It bears beautiful, big flowers of various colours and sizes that predominate especially during the summer [3].

Unfortunately, there are factors which inhibit frangipani growth, i.e. pest and pathogen attacked. One of pathogens which could attack frangipani plant is virus. Preliminary surveys in the fields of Pingtung, Kauhsiung and Tainan County showed that some frangipani plants are indicating attacked by viruses based on foliar symptoms about $30 \%$ severity (unpublished data, 2012). This condition encourages the research about molecular characterization

\footnotetext{
* Correspondence author:

Fery Abdul Choliq

Email : feryac@ub.ac.id

Address : Department of Plant Protection, Faculty of Agriculture, University of Brawijaya, J. Veteran Malang, 65145
}

(electron microscopy, virus purification, and RT$P C R$ ) of unknown reported mosaic disease of Plumeria sp. in Taiwan. The objective of this study was to identify the virus which attacked Plumeria sp.

\section{MATERIALS AND METHODS Virus Source and Isolation}

Frangipani plants showing symptom caused virus including mosaic and leaf distortion were collected in Pingtung County, Taiwan by random sampling method from 100 plants as sampel. Symptoms were recorded (photographed) at Plant Protection Laboratory, Department of Plant Medicine, National Pingtung University of Science and Technology (NPUST) Taiwan. Then, virus was isolated by mechanical inoculation from the infected frangipani leaf to indicator plant, Chenopodium quinoa Willd. and then local lesions of $C$. quinoa were collected and maintained on C.quinoa leaves by three passages [4]. Plants' leaves were dusted with carborundum (400 mesh) and $0.1 \mathrm{M}$ phosphate buffer (PB) containing virus-stabilizing additivies of $0.1 \%$ 2-mercaptoethanol, pH 7.0 was used [5]. The virus was subsequently multiplied on $C$. quinoa Plants because it's highly susceptible and easy to growth and maintained in the laboratory at room temperature with supplemented flourescene light providing a photoperiod at 
12L:12D. The virus isolate was temporary designated as Frangipani-Taiwan 1 (Fr-T1).

\section{Electron Microscopy (Negative Staining)}

Virus particles from $C$. quinoa and frangipani leaf extracts were one drop floated onto electron microscopy Formvar-fronted, carbon coated, 200 mesh copper grids and incubated for five minutes. Then, the grids were washed with 10 drops of distilled water, negatively stained with 6 drops of $2 \%$ aqueous uranyl acetate $(\mathrm{pH} 5.0)$ and incubated for five minutes. Then, all the fluid was removed by touching the edge of the grid carefully with a filter paper [6]. Then air dried before positioning the grid in a suitable container (grid storage box) and examination with Hitachi 7500 electron microscope. Particle size was determined by measuring the average of length and diameter of 100 virions.

The virus isolate Fr-T1 was partially purified according to the method by Dijkstra and de Jager [7] with slight modification as follows: infected $C$. quinoa leaves with local lesion symptoms were kept at deep freezer $\left(-80^{\circ} \mathrm{C}\right)$ homogenized with one volume $(\mathrm{v} / \mathrm{w}) 0.5 \mathrm{M}$ phosphate buffer, $\mathrm{pH} 8.5$, containing $0.01 \mathrm{M}$ Na-EDTA. Then strained through 2 layer cheesecloth. After filtering through cheesecloth, the extract was clarified by adding $12 \%$ chloroform $\left(4^{\circ} \mathrm{C}\right)$ and stirred for 2 minutes. Then continued by centrifuged at $8000 \mathrm{rpm}$ for 20 minutes (R14A rotor, Hitachi CR21G, Japan). Collect the supernatant and layered on the top

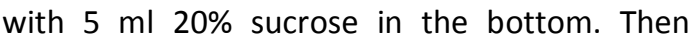
centrifuged at $28.000 \mathrm{rpm}$ for 2.5 hour (P70T rotor, Hitachi CP90WX, Japan).

The pellet was resuspended in borate buffer $\mathrm{pH} 8.2$ containing $0.01 \mathrm{M}$ Na-EDTA. Then centrifuge at 3,000 rpm for 10 minutes (R20A2, Hitachi CR21G, Japan). Collect the supernatant and centrifuged in swing-bucket rotor at 38,000 rpm for 23 hours (RPS40T-1180 rotor, Hitachi $\mathrm{CP90WX}$ ) in $30 \% \mathrm{Cs}_{2} \mathrm{SO}_{4}$ by density gradient centrifugation (Swing-bucket rotor). Dialysed the virus band with phosphate buffer $0.01 \mathrm{M}, \mathrm{pH} 7.0$ and stirred for 16 hours at $4{ }^{\circ} \mathrm{C}$. Then, the purified virus was test by measuring wavelength absorbance at range 220-320 nm (Hitachi U2001 spectrophotometer). Virus concentration (c in $\mathrm{mg} \cdot \mathrm{mL}^{-1}$ ) were calculated by formula [7]:

$$
c=A_{260} / E x \text { dilution factor }
$$

Determination of the Molecular Weight of Viral Coat Protein by SDS-Polyacrylamide Gel Electrophoresis (SDS-PAGE)

Healthy C. quinoa leaf, infected C. quinoa leaf, healthy frangipani leaf, field mosaic frangipani leaf, and purified virus isolate Fr-T1 were homogenized with $1: 4(\mathrm{w} / \mathrm{v}) \quad 0.5 \mathrm{M}$ phosphate buffer, $\mathrm{pH}$ 7.0. Then centrifuged the samples on centrifuge $10,000 \mathrm{rpm}$ for $10 \mathrm{~min}$ and collected the supernatant. The extracts were analyzed by SDS-polyacrylamide gel electrophoresis (SDS-PAGE) with $12 \%$ running gel and 5\% stacking gel. Mix the samples with dye on comparison 4:1 in microtube. Then heat the microtube on dry bath incubator (Violet Bioscience, Inc.) at $100^{\circ} \mathrm{C}$ for $3 \mathrm{~min}$. Load Protech (Prestainde Protein Marker) $5 \mu \mathrm{l}$ as marker and $10 \mu$ of each samples into the wells in the stacking gel. Start the electrophoresis with 70 voltage (V) during 30 minutes and continue with $120 \mathrm{~V}$ during $70 \mathrm{~min}$. After finish running, the gel were stained with Coomassie Blue and shake gently on Orbital Shaker PSU-10i (Grant-Bio) with $70 \mathrm{rpm}$ for $1 \mathrm{~h}$. Replace the Comassie Blue with destaining buffer $(100 \mathrm{ml}$ methanol, glacial acetic $70 \mathrm{ml}$, add $\mathrm{ddH}_{2} \mathrm{O}$ to $1,000 \mathrm{ml}$ ) and shake gently on Orbital Shaker PSU-10i (Grant-Bio) with $70 \mathrm{rpm}$ for $24 \mathrm{~h}$. Protein bands are stained and the molecular weight of the viral coat protein was determined by comparing migration of the viral protein in the gel with that of marker protein and run in parallel lanes [7].

\section{Amplification and Analysis of Nucleic Acid Sequences \\ Extraction of Total RNA}

Purified virus of virus isolate Fr-T1, healthy Nicotina benthamiana and C. quinoa leaf, Tobacco mosaic virus (TMV) infected tomato and N. tabacum samples and Odontoglossum ringspot virus (ORSV) were prepared. Each sample take $5 \mu$ and use RNA extraction kit (Directzol $^{\text {TM }}$ RNA miniprep) to extract total RNA from the each sample according to the manufacturer's instructions (The Epigenetics Company).

\section{Reverse Transcription-Polymerase Chain Reac- tion (RT-PCR)}

One-tube of RT-PCR reactions $(25 \mu \mathrm{l})$ were performed. A final concentration of $1 \mu \mathrm{M}$ for each tobamoviruses degenerate primers TobRT up1 (5'-GARTAYSCIGCIYTICARAC-3') and TobRT do2 (5' BGCYTCRAARTTCCA-3'), was used. The cycling profile was as follows : first step at $43^{\circ} \mathrm{C}$ for $60 \mathrm{~min}$, second step at $50^{\circ} \mathrm{C}$ for $2 \mathrm{~min}$, third 
step at $94^{\circ} \mathrm{C}$ for $4 \mathrm{~min}$; five cycles segmented into step (a) $30 \mathrm{~s}$ at $95^{\circ} \mathrm{C}$, step (b) $30 \mathrm{~s}$ at $43^{\circ} \mathrm{C}$, step (c) $15 \mathrm{~s}$ at $72^{\circ} \mathrm{C}$; 35 cycles segmented into step (a) $30 \mathrm{~s}$ at $95^{\circ} \mathrm{C}$, step (b) $30 \mathrm{~s}$ at $46^{\circ} \mathrm{C}$, step (c) $15 \mathrm{~s}$ at $72^{\circ} \mathrm{C}$, followed by a final extension step at $72^{\circ} \mathrm{C}$ for 2 min [8]. Amplification was carried out in Px2 Thermal cycler (Thermo Electron Corporation).

\section{Nested Polymerase Chain Reaction (PCR)}

Nested PCR reactions $(20 \mu l)$ were performed using $1 \mu \mathrm{l}$ of the first RT-PCR product mixed with PCR master kit (GeneMark, Taiwan) and $1 \mu \mathrm{M}$ of each degenerate primer TobN up3 (5'-GGCGYTGCARACIATHGTITAYCA-3'), TobN do4 (5' GTRTTICCIATRAAIGTIGTIACRTC-3') and TobN do4G (5' GCCGATRAAGGTGGTGACRTC-3'). The cycling profile consisted of a denaturasing step at $95^{\circ} \mathrm{C}$ for $3 \mathrm{~min}$, two cycles segmented into step (a) $20 \mathrm{~s}$ at $95^{\circ} \mathrm{C}$, step (b) $15 \mathrm{~s}$ at $51^{\circ} \mathrm{C}$, step (c) $5 \mathrm{~s}$ at $72^{\circ} \mathrm{C} ; 26$ cycles segmented into step (a) $20 \mathrm{~s}$ at $95^{\circ} \mathrm{C}$, step (b) $15 \mathrm{~s}$ at $61^{\circ} \mathrm{C}$, step (c) $5 \mathrm{~s}$ at $72^{\circ} \mathrm{C}$, followed by a final extension step at $72^{\circ} \mathrm{C}$ for $2 \mathrm{~min}$ [8]. Amplification were carried out in Px2 Thermal cycler (Thermo Electron Corporation).

\section{Electrophoresis Analysis}

Electrophoresis analysis was used to ascertaining DNA product was amplified by RTPCR and nested PCR. Get $1 \mu$ loading dye with 5 $\mu l$ PCR product uniformly mixing. Load $2 \mu \mathrm{l}$ marker and each sample inside the horizontal electrophoresis analysis $(1.5 \%$ agarose $+0.5 \mu \mathrm{l}$ Save view DNA stain). Running on electrophoresis machine (Major Science) with $120 \mathrm{~V}$ electricity for $20 \mathrm{~min}$. Then, visualized under UV light and estimate the amplified product.

\section{RESULT AND DISCUSSION Virus Isolation}

Frangipani plants exhibiting virus-like disease collected in Pingtung County (South Taiwan) which showed mosaic and leaf distortion on young leaf of frangipani plants (Fig. 1). Frangipani plants exhibiting virus-like disease was indicated on several city (Pingtung, Kauhsiung and Tainan). The symptom is similar according to previous study [9] noted that the leaves of frangipani infected by virus was showed chlorotic ringspots or mosaic and were often distorted. In addition, the virus induced chlorotic ringspot and mosaic, and often distortion on leaves of frangipani [10]. Mechanical inoculation to indicator plants
(Chenopodium quinoa) and isolation by three time single lesion showing local lesion on leaves (Fig. 2).

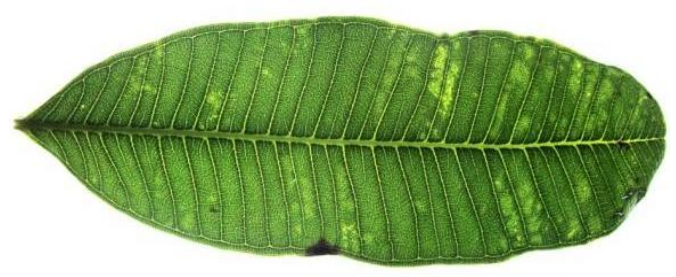

Figure 1. Mosaic symptom of frangipani leaves on the field.

Mechanical inoculation to indicator plant ( $C$. quinoa) and maintenance by three time single lesion showing local lesion (Fig. 2). The local lesion were produced on the inoculated leaves of C. Quinoa [9]. The virus induces chlolotic ringspots or mosaic, and oftendistortion on leaves of frangipani, and severe mosaic symptoms occur on leaves of virus-infected Nicotiana benthamiana [10].

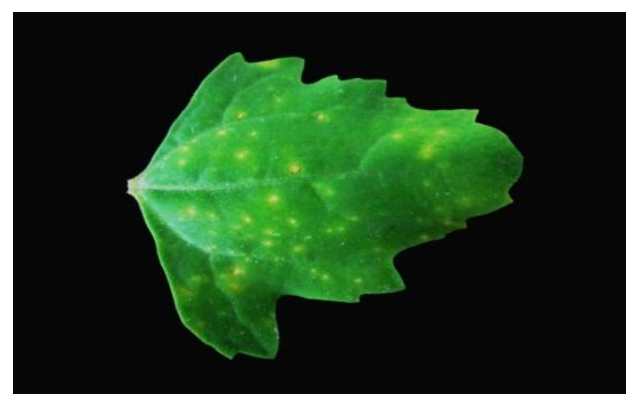

Figure 2. The local lesions caused by viru isolate Fr-T1 on Chenopodium quinoa leaf

\section{Electron Microscopy}

Rigid, rod-shaped particles with average length of 250-300 nm x $18 \mathrm{~nm}$ were seen in negatively stained preparations from infected frangipani leaves, infected $\mathrm{C}$. quinoa leaves after three times single lesion and purified virus isolate Fr-T1 (Fig. 3). Electron microscopy test were continued for counting the average size (length and diameter) of 100 virions.

Rigid, rod-shaped particles with average length of $300 \mathrm{~nm} \times 18 \mathrm{~nm}$ were seen in negatively stained preparations has constant results from infected frangipani leaves and purified virus isolate (Fig. 3). Particle morphology which has rod-shaped, usually straight with the size about $300 \mathrm{~nm}$ long and 18 $\mathrm{nm}$ in diameter are characteristic similar to FrMV [7,11,12]. 


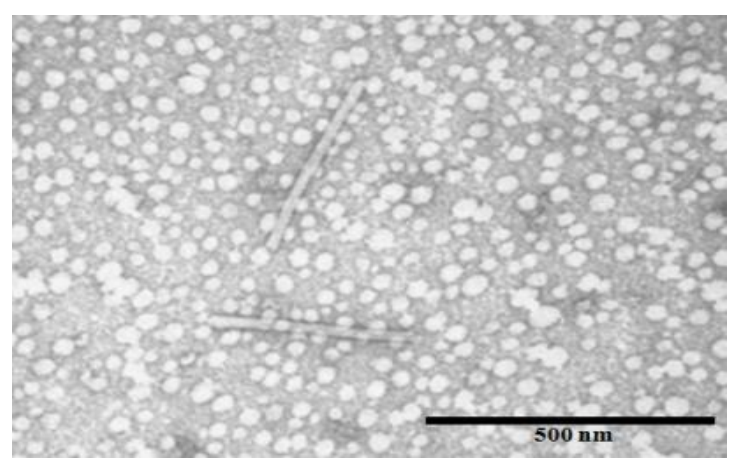

Figure 3. Electron micrograph of negatively stained ( $2 \%$ uranyl acetate) virus particles from crude sap of frangipani leaves showing mosaic symptom (Bar=500nm).

The virus were checked the absorbance value by spectrophotometer and showed the curve spectrum rises rather slowly as the wavelength decreases from 300 to $250 \mathrm{~nm}$, and then rapidly as the wavelength decreases below $250 \mathrm{~nm}$. The purified virus showed the typical UV spectrum of nucleoprotein with $A_{260} / 280$ value is 1.29 and maximum and minimum absorption at $260 \mathrm{~nm}$ and $249 \mathrm{~nm}$, respectively (Fig. 4). There is also evidence that at least at wavelength longer than $250 \mathrm{~nm}$, the virus protein and RNA is partially protected from damage by UV [13].

The molecular weight of coat protein of the virus was estimated $19.5 \mathrm{kDa}$ by electrophoresis in sodium dedocyl sulfate polyacrylamide gel (SDS-PAGE) (Fig. 5). Lane 1 and 3 are healthy leaf samples (C. quinoa and field mosaic frangipani leaf) that did not show band on $19.5 \mathrm{kDa}$, but infected leaf samples (lane 2 and 4) were showing band with identical molecular weight compare to purified virus isolate Fr-T1 (19.5 $\mathrm{kDa})$. This data is slighty different from known molecular weight of tobamoviruses genus, such as the coat protein of TMV has molecular weight of $17-18 \mathrm{kDa}[14,15]$. The slight difference of coat protein molecular weight between virus isolate Fr-T1 and other tobamoviruses may be as a result when draw horizontal line for comparing marker and samples bands on gel.

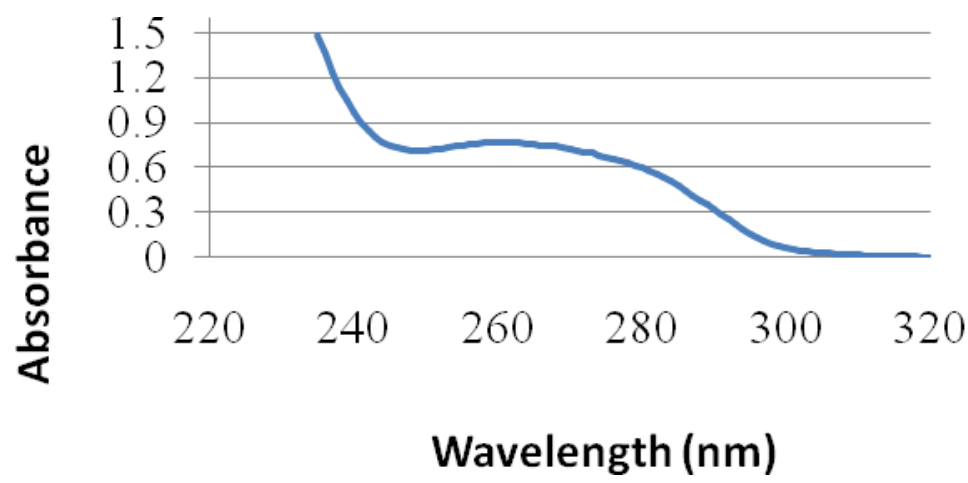

Figure 4. The ultraviolet absorption spectrum of purified preparation of virus isolate Fr-T1.

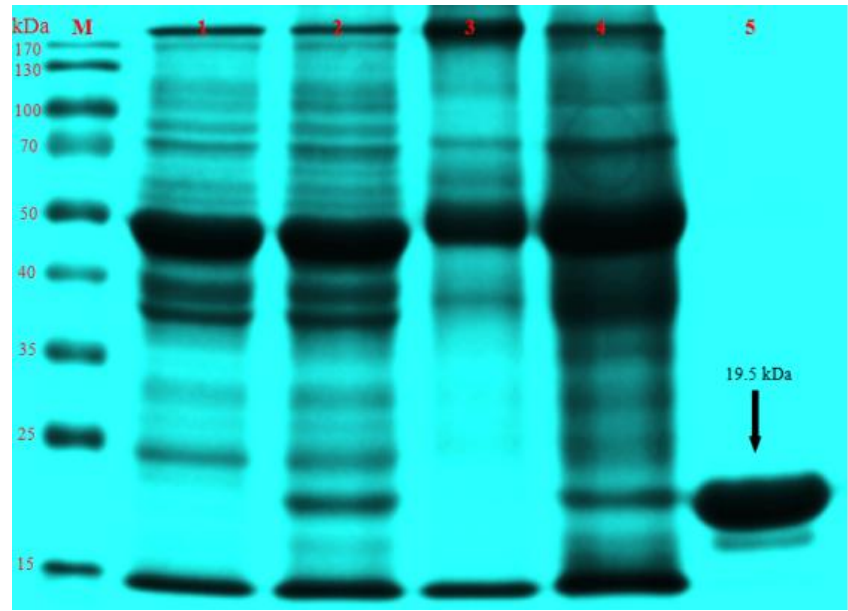

Figure 5. The determination of viral coat proteins molecular weight of virus isolate Fr-T1 by SDS-polyacrylamide gel electrophoresis (SDS-PAGE). (M : Marker, 1 : Healthy Chenopodium quinoa leaf, $2:$ Infected Chenopodium quinoa leaf, 3 : Healthy frangipani leaf, 4 : Field mosaic frangipani leaf, 5 : purified virus isolate Fr-T1). 


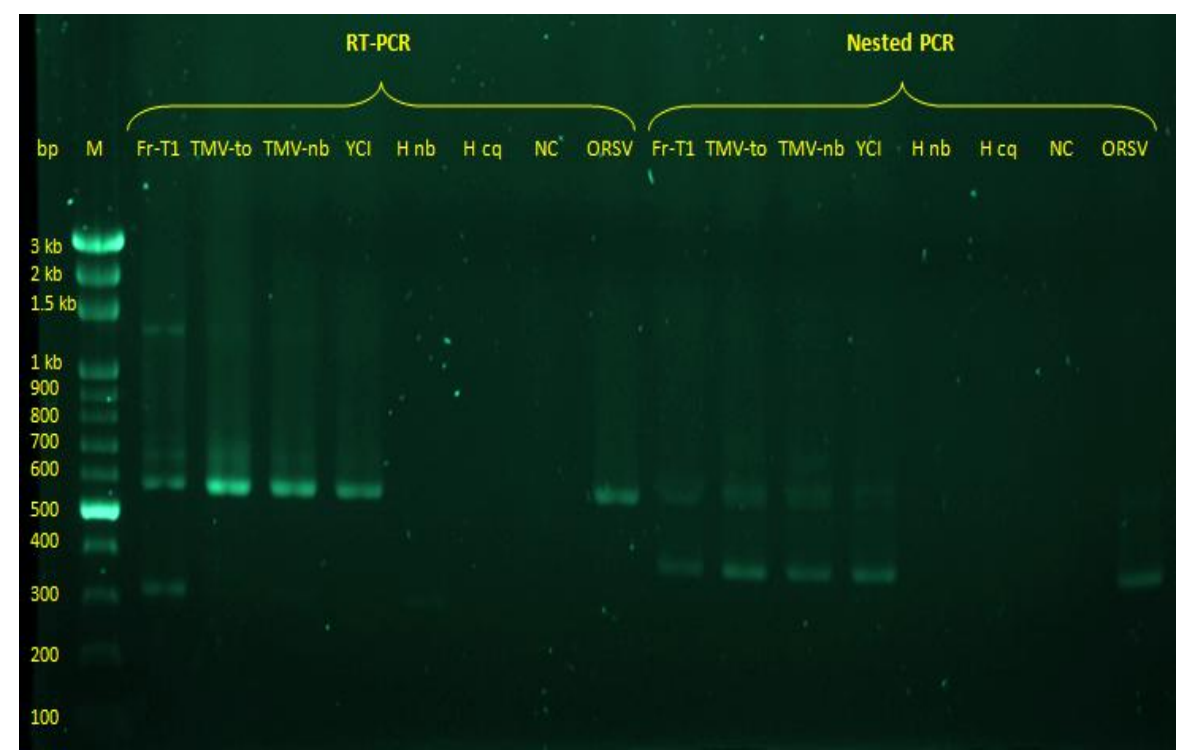

Figure 6. Agarose gel electrophoresis analysis of RT-PCR and Nested PCR products obtained from different tobamovirus isolates. (M : Marker, Fr-T1 : Frangipani virusisolateTaiwan 1, TMV-to : Tobacco mosaic virus infected tomato, TMV$\mathrm{nb}$ : Tobacco mosaic virus infected Nicotiana tabacum, $\mathrm{YCl}$ : Yocai virus isolate from company, $\mathrm{H} \mathrm{nb}$ : Healthy Nicotiana tabacum, H cq : HealthyChenopodium quinoa, NC : Negative control, ORSV : Odontoglossum ringspot virus).

Agarose gel electrophoresis analysis of RTPCR (Fig. 6 left) and Nested PCR (Fig. 6 right) products obtained from different tobamovirus isolates were conducted for detection and partial characterization of unknown species. The virus isolate Fr-T1 could be amplified by RT-PCR using degenerate primers TobRT up1 and TobRT do2 and resulted $568 \mathrm{bp}$. This length are similar comparing to other tobamoviruses isolates (TMVto,TMV-nb and ORSV) [8].

Nested PCR assays using Fr-TI isolate from RTPCR product yielded about $400 \mathrm{bp}$ and this amplification products is similar as expected for all tobamovirus isolates tested (TMV-to,TMV-nb and ORSV), but not shown on control (Healthy Nicotina benthamiana and C. quinoa) (Fig. 7 right). Degenerate primers for detection of tobamoviruses by RT-PCR can be more efficient for the amplification of most members of a gene family, also allowing for the detection of new and unidentified virusspecies, followed by a nested PCR amplification that increased specificity and sensitivity of detection [8].

\section{CONCLUSION}

Based on these results, it was confirmed that the rigid rod-shaped virus isolated from mosaic symptom of frangipani leaves has length of 300 $\mathrm{nm} \times 18 \mathrm{~nm}$ and could be identified as FrMV, belongs to Tobamovirusupon from its molecular (SDS-PAGE, RT-PCR, Nested PCR and nucleotide sequence comparison) characterizations. This is the first report that FrMV infecting frangipani (Plumeria sp.) in Taiwan.

\section{REFERENCES}

[1] Eggli, U. 2002. Illustrated handbook of succulent plants (Dicotyledons). Springer. Switzerland.

[2] Tao, L.P., A.J.M. Leeuwenberg, D.J. Middleton. 1995. Apocynaceae. Flora of China 16. 143-188.

[3] Chung, W.H., C.P. Abe, Y. Yamaoka, T.W. Haung, M. Kakishima. 2005. The first report of Plumeria (Frangipani) rust disease caused by Coleosporium plumeriae in Taiwan. BSPP. New Disease Reports 11: 16.

[4] Chen, T.H., Y.T. Lu. 1995. Partial characterization and ecology of bamboo mosaic Potexvirus from bamboos in Taiwan. Plant Pathol. Bull. 4. 83-90.

[5] Valiunas, D., M. Samuitiene, M. Navalinskiene, R.E. Davis. 2008. Identification of viral and phytoplasmal agenta causing disease in Gaillardia Foug. Plants in Lithuania. Agro. Res. 6. 109-118.

[6] Hajibagheri, M.A. 1999. Electron microscopy methods and protocols. Humana Press. Totowa. New Jersey.

[7] Dijkstra, J., C.P. de Jager. 1998. Practical plant virology: Protocols and exercises. Springer-Verlag. Berlin. 
[8] Dovas, C.I., K. Efthimiou, N.I. Katis. 2004. Generic detection and differentiation of tobamoviruses by spot nested RT-PCR-RFLP using dl-containing primers along with homologous dG-containing primers. J. Virol. Methods. 117. 137-144.

[9] Francki, R.I.B., M. Zaitlin, C.J. Grivel. 1971. An unusual strain of tobacco mosaic virus from Plumeria acutifolia. Aust. J. Biol. Sci. 24. 815-818.

[10] Lim, M.A., J.S. Hong, Y.S. Song, K.H. Ryu. 2010. The complete genome sequence and genome structure of Frangipani mosaic virus. Arch. Virol. 155. 1543-1546.

[11] VIDE Database. 2011. Plant Viruses Online: Frangipani mosaic virus. Available at: http://sdb.im.ac.cn/vide/descr345.htm.

[12] Varma, A., A.J. Gibbs. 1970. Frangipani mosaic virus. Available at: http://www. dpvweb.net/dpv/showdpv.php?dpvno=196.

[13] Kleczkowski, A., A.D. McLaren. 1967. Inactivation of Infectivity of RNA of Tobacco Mosaic Virus during ultraviolet irradiation of the whole virus at two wavelengths. J. Gen. Virol. 1. 441-448.

[14] Astier, S., J. Albouy, Y. Maury, C. Robaglia, H. Lecoq. 2007. Principles of plant virology: genome, pathogenicity, virus ecology. Science Publisher. USA.

[15] Hull, R. 2009. Comparative plant virology, $2^{\text {nd }}$ Ed. Academic Press. UK. 